\title{
Study On the Development of Penology In China
}

\author{
Chen Di \\ Jiangxi University of Technology
}

\begin{abstract}
- 60 year development history of penology in China can be divided into three stages, namely, establishment and devious development stage, stagnation stage and revival and development stage. During which, researches in terms of penology have achieved remarkable progress, yet also have demerits. Researches in the future should try unremitting efforts to construct people-oriented criminal theory so as to scientifically carry out researches in terms of jurisprudence system and meanwhile strengthen the analysis on penology theory in the West. This paper is conducted from the perspective of criminology and penology to compare their nature and value goal. Besides, it also takes victimless crime theory related to victim theory as the perspective so as to elaborate the preconditions, ontology setting and connotation of victim theory.
\end{abstract}

KeyWords-Criminology; Penology; Function

\section{INTRODUCTION}

Penology is normative, which asks almost stringent requirements on every basic theory. Victims, as an important part of penology relations must have an accurate definition. Crime and victimization have unity of opposites in criminology. Besides, in penology, previous researches only give integrated regulations on the theory of crime and criminals, which lack necessary concern on victims who play an important role in penology relations. Therefore, this crime relation-namely such binary penology relation shall blur and play down the nature of interpersonal conflict and as a result, victims can only passively rely on the criminal procedure they do not have the right to participate in to seek right relief. In addition, victims are in a weak position after being injured because they cannot positively carry out disciplinary action which shall inevitably lead to the weakening of practical value in penology.
This paper takes victims in criminology as the basic point which yet ignores the differences between criminology and penology because they have differences in terms of research objects and targets. However, it has to be admitted that victims are closely related to criminology yet there are combination points between criminology and penology. Therefore, while studying on the concept of victims in penology, we have to take advantage of the basic theories of criminology and their combination shall be the premise to research on penology and relevant theories of victims.

\section{EMERGENCE OF PENOLOGY}

Penology, as the science to research on the criminal law emerges along with the appearance of criminal law. In the long development process, and deepening understanding of crime and penalties, a dazzling array of criminal law culture heritage is accumulated which becomes important parts of human civilization. In ancient China, criminal law was developed and its main body is criminal law science which is modern penology. For example, in Spring and Autumn Period there so-called criminal law had appeared. However, we believe that penology, as an independent course emerges in modern times. In 1764, On Crimes and Punishments written by Beccaria, a famous Italian expert of criminal was published, which marks the formal emergence of penology. Afterwards, with timeless efforts of Feuerbach, Cesare Lombroso, Pamphili and Liszt, criminal classical school and criminal positivism school (including school of criminal anthropology and criminal society) successively appeared and they established and developed theoretical system of criminal law. This paper belongs to regulated penology, which takes current criminal rules as objects. Regulated penology is the basis of penology and introduction knowledge. 


\section{MAIN DEMONSTRATION FOR PENOLOGY} ADVANCEMENT IN CHINA

\section{A. Big leap in terms of academic research quantity and quality}

The research results of penology as mentioned above, only have four teaching materials and one article called On Accomplice from 1949 to 1979; at present, there are more than 10 teaching materials or above 20 if compiling textbooks are included. Concerning penology monographs, there are more than 100 types from 1981 and 1991. If counted from 1981 to the end of 2008, there are several hundreds. In addition, the paper number is soaring comparing to 30 years ago. Based on the above, we can see the big leap in terms of academic research quantity and quality.

\section{B. One thriving research result to diverse results}

As mentioned above, there were only four teaching materials and one article called On Accomplice 30 years ago, which can deemed as dominant ideology. Even though different opinions emerge in concrete problems, they are contentions of dominant ideology because they are productions of Soviet Criminal Law theory. In another word, they are constructed based on the blueprint of criminal jurisprudence system; moreover, On Accomplice is also experience while studying Soviet's Theory of Joint Crime; furthermore, compromise behavior belongs to Theory of Joint Crime and at that time, the dominant ideology ruled all the land in penology circle.

\section{FUNCTIONS OF PENOLOGY}

The functions of penology can be beckoned as a basic theoretical issue which to some extent affects its correct application. However, the penology circle in China does not pay attention to this problem. Various penology works published do not elaborate this issue; besides, there are few papers published in journals and magazines. This author shall come up with several ideas on this problem.

Conduct regulation function refers to the clear function of regulating criminal behaviors. Its concrete contents include, criminal law specifies some behaviors as crimes with punishment which are valueless (evaluative function); at the same time, it commands people to not implement this behavior (decision function).
Legal interest protection function can protect legal interest from being damaged and threatened. Criminal behaviors shall damage and threaten legal interest while criminal laws prohibit and punish these behaviors.

Freedom protection function can protect citizens' individual freedom from being damaged. According to the statutory principle of crime, as long as the behavior of actors does not constitute a crime regulated by criminal law, he shall free from penalty which limits the mobilization of penalty power; besides, only regulated penalty can be carried out which cannot go beyond the scope and can help criminals exempt from improper penalty. Therefore, criminal law is Great Charter of the kind and criminals.

\section{CONCLUSION}

Based on the fundamental of criminology, the research scope should be established based on subject itself to have a comprehensive understanding of victims which belong to the basic theory of criminology so as to combine the ought of criminology and seinsbegriffe of penology in victimology in the premise of knowing their difference to realize the fundamental target. The most fundamental and important value of criminal law is to act as the means to protect and safeguard national power. It is the best explanation of criminal law's existence in Germany. To explain why human beings should have criminal law based on the laws only adapted to some countries is also biased. Therefore, the author holds the idea that we have to strengthen the analysis and look upon its theories from various perspectives while referring to the criminal law theories of western countries.

\section{REFERENCES}

[1] Simon J. Managing the monstrous: Sex offenders and the new penology.[J]. Psychology Public Policy \& Law, 2003, 4(1-2):301-316

[2] Simon J. Managing the monstrous: Sex offenders and the new penology.[J]. Psychology Public Policy \& Law, 2003 4(1-2):301-316

[3] Sparks R. Degrees of Estrangement:: The Cultural Theory of Risk and Comparative Penology[J]. Theoretical Criminology, 2001, 5(2): $159-176$

[4] Dirk V Z S, Snacken S. Principles of European prison law and policy : penology and human rights[M]// Oxford University Press, 2011

[5] Cheliotis L K. How iron is the iron cage of new penology?: The role of human agency in the implementation of criminal justice policy[J]. Punishment \& Society, 2009, 8(3):313-340.

[6] Brownlee, Ian. New Labour - New Penology? Punitive Rhetoric and the Limits of Managerialism in Criminal Justice Policy[J] Journal of Law \& Society, 1998, 25(3):313-335. 
[7] Miller T A. Citizenship \& Severity: Recent Immigration Reforms and the New Penology[J]. Social Science Electronic Publishing, 2011, 17.

[8] Blomberg T, Yeisley M, Lucken K. American penology: Words, deeds, and consequences[J]. Crime Law \& Social Change, 1997, 28(3-4):269-286.

[9] Shichor D. Three Strikes as a Public Policy: The Convergence of the New Penology and the McDonaldization of Punishment[J]. Crime \& Delinquency, 1997, 43(4):470-492.
[10] Kempf-Leonard K, Peterson E S L. Expanding Realms of the New Penology: The Advent of Actuarial Justice for Juveniles[J]. Punishment \& Society, 2000, 2:66-97.

[11] Blomberg T G, Lucken K. American penology : a history of control[M]// Aldine de Gruyter, 2000.

[12] 【Jeffery C R, Korn R R, Mccorkle L W. Criminology and Penology[J]. Journal of Criminal Law Criminology \& Police Science, 1960, 51. 